\title{
Story from Realm of Maps in Regensburg
}

\author{
Beata Medyńska-Gulij ${ }^{\mathrm{a} *}$, Tillmann Tegeler ${ }^{\mathrm{b}}$, Hans Bauer ${ }^{\mathrm{b}}$, Krzysztof Zagata ${ }^{\mathrm{a}}$, Łukasz Wielebski ${ }^{\mathrm{a}}$, \\ Ulf Brunnbauer $^{\mathrm{b}}$ \\ ${ }^{a}$ Adam Mickiewicz University Poznan, Department of Cartography and Geomatics, Poland,bmg@amu.edu.pl, \\ krzysztof.zagata@amu.edu.pl,lukasz.wielebski@amu.edu.pl \\ ${ }^{b}$ Leibniz Institute for East and Southeast European Studies, Regensburg, Germany, tegeler@ios-regensburg.de, hbauer@ios- \\ regensburg.de,brunnbauer@ios-regensburg.de \\ * Corresponding author: Beata Medyńska-Gulij, bmg@amu.edu.pl
}

Keywords: historio-geographical space, realm of maps, cartographic shapes, people movement, Europe, geomedia

\begin{abstract}
:
The research was based on cartographic, geographic and historical knowledge as well as proven methods for creating short scenario for a film with map as the core of the story. The main aim of this study was to give a possibility to immerse himself in the 'Realm of Maps' in Regensburg to answer questions - about history of people movement in Southeast Europe - through maps, cartographic shapes and geomultimedia.

With a support of experts on historical sources from the Leibniz Institute for East and Southeast European Studies we constructed Realm of Maps for the leitmotiv 'People Movement in Southeast Europe'. This construction consisted the following components: digital maps in GeoPortOst using internet tools that enable it to penetrate them and intervene interactively in their cartographic content; historical and railway atlases, contemporary and old political and hypsometric wall maps, old folio maps, monographs and bibliographies. On one big paper sheet for creating a graphic scenario of a planned story we focused on key historical events in geographical space, such as: beginning of settlement organization in Banat after the Habsburg victory over Ottomans and mass emigration to the USA. We linked these events with their visualization on maps, e.g. the The War Theatrum designed by Homann around 1718. Our activities in the Realm of Maps were recorded on photos and films from 360-degree-camera. The Danube was the geographic link between all these events, so in our story its shape plays the main role.

The collected materials were used in the laboratory in the Department of Cartography Geomatics to create a short film story. In this story we used different kind of media related to pragmatic rulers of cartographic design: brief inscriptions and years, highlighting the Danube blue line, three acting researchers with dialogue balloons on maps, 'immersion' into the map room by photos from spherical view, maps on the table and wall maps, flyover with 3D hypsometric map, animation with political maps from 1647 to 2021, zooming in on the content of old maps, and animation with pictorial signs and numbers of people, and dynamic classical music.
\end{abstract}

The video was uploaded to YouTube: https://www.youtube.com/watch?v=E-mChqmYn2A

The result of the project is aimed at active users of maps and other cartographic presentations especially to geographers and historians who are interested in interdisciplinary discussions about the development of new perspectives for exploring the region of Eastern and Southeastern Europe. 